\title{
Malakoplakia of the testis and its relationship to granulomatous orchitis
}

\author{
JOHN MCCLURE \\ From the Department of Pathology, The Queen's University of Belfast, Institute of Pathology, Grosvenor \\ Road, Belfast, Northern Ireland, UK
}

SUMmARY The chance finding of two cases of undiagnosed malakoplakia in the files of the Department of Pathology, Queen's University Belfast prompted a systematic study of all cases of inflammatory testicular and epididymal disease diagnosed in that department during a 43-year period from 1934 to 1977. A total of 71 cases was studied, and no additional example of malakoplakia was found. In the Belfast collection, there is one other example of testicular malakoplakia and therefore a total of three cases in 74 examples of inflammatory testicular and epididymal disease $(4 \cdot 3 \%$ incidence). In the series there were 10 cases of granulomatous disease $(13 \cdot 5 \%)$.

The world literature on testicular malakoplakia has been reviewed, and typical and atypical features have been determined. Also a comparison has been made between testicular malakoplakia and granulomatous orchitis, and the relationship between these conditions is discussed.

Malakoplakia is an uncommon condition described initially by Michaelis and Gutmann ${ }^{1}$ and characterised by von Hansemann. ${ }^{2}$ Malakoplakia is probably a chronic inflammatory process, and the most commonly affected site is the urinary bladder although involvement of extravesical sites is being reported with increasing frequency. Such sites include kidneys, urinary pelvis and ureters, ${ }^{3}$ testis, ${ }^{4}$ prostate,${ }^{78}$ and colon. ${ }^{9}$

Malakoplakia is characterised by the presence of large cells with abundant, eosinophilic cytoplasm (von Hansemann cells). In their cytoplasm there are typical inclusions called Michaelis-Gutmann (MG) bodies. These range from 2 to $10 \mu \mathrm{m}$ in diameter and give a basophilic reaction with haematoxylin dye. Special stains reveal the presence of calcium and sometimes iron salts. Frequently MG bodies have a concentric laminated (targetoid or 'owl's eye') appearance.

The chance finding of two cases of testicular malakoplakia in the files of the Department of Pathology, Queen's University Belfast prompted a systematic review of all cases of inflammatory and testicular disease in an attempt to discover further examples of malakoplakia. The results of this review, detailed case histories, and histopathological findings of the two cases of testicular malakoplakia mentioned

Received for publication 29 October 1979 above and a survey of the world literature are presented herein.

\section{Material and methods}

All cases of inflammatory disease of the testis and epididymis diagnosed in the Department of Pathology, Queen's University Belfast during the period 1934 to 1977 were reviewed. A total of 74 cases was studied. The cases were grouped by the anatomical site of the inflammatory process (ie, involvement of epididymis and testis, testis only, and epididymis only) and by the character of the inflammatory process (ie, acute, acute and chronic, chronic, granulomatous, and malakoplakic). These groupings are displayed in the Table. Cases of tuberculosis were excluded.

Fresh sections of all available blocks were cut and stained with haematoxylin and eosin (HE). Examples of granulomatous disease and suspected examples of malakoplakia were also stained with von Kossa, periodic acid Schiff (PAS), Ziehl Nielsen (ZN), alizarin red S, Perl's Prussian blue, the Gram stain, and the Warthin-Starry method.

\section{Case reports}

CASE 1

A 55-year-old man was admitted to hospital with a 
Table Character of inflammatory response in relation to anatomical site

\begin{tabular}{|c|c|c|c|c|}
\hline \multirow[t]{2}{*}{ Cbaracter of inflammation } & \multicolumn{3}{|l|}{ Anatomical site } & \multirow[t]{2}{*}{ Total } \\
\hline & Testis and epididymis & Testis only & Epididymis only & \\
\hline $\begin{array}{l}\text { Acute } \\
\text { Acute/chronic } \\
\text { Chronic } \\
\text { Granulomatous } \\
\text { Malakoplakic }\end{array}$ & $\begin{array}{r}3 \\
12 \\
6 \\
1 \\
0\end{array}$ & $\begin{array}{r}5 \\
3 \\
10 \\
9 \\
3\end{array}$ & $\begin{array}{r}6 \\
6 \\
10 \\
0 \\
0\end{array}$ & $\begin{array}{l}14(18.9 \%) \\
21(28.3 \%) \\
26(35.0 \%) \\
10(13.5 \%) \\
3(4.3 \%)\end{array}$ \\
\hline
\end{tabular}

history of pain in the left testis for four weeks, and pain on micturition and frequency for five weeks. Clinical examination revealed a firm, tender swelling in the left side of the scrotum with enlarged tender left inguinal lymph nodes. Rectal examination revealed a firm, enlarged prostate.

Routine haematological and biochemical tests were within normal limits. Urine cultures revealed a significant growth of Escherichia coli on two occasions. The sputum was found to contain acid and alcohol fast bacilli (AAFB) on one occasion (the urine was free of AAFB). There was a history of pulmonary tuberculosis in 1959. Currently, the chest $x$-ray showed left apical calcification but no sign of active disease.

Exploration of the scrotum resulted in removal of the left testis and epididymis (weight $60 \mathrm{~g}$ ). The cut surface of the testis was yellow-brown and homo- geneous, measuring $50 \times 30 \times 40 \mathrm{~mm}$. Histologically, in some areas, the tubular architecture was completely replaced by a cellular infiltrate composed largely of macrophages admixed with a smaller number of lymphocytes (Fig. 1). Many of the macrophages contained faintly basophilic MichaelisGutmann (MG) bodies, generally of nuclear size (Fig. 2). Occasional extracellular MG bodies were seen. Histochemically, the MG bodies reacted positively with the PAS, alizarin red $\mathrm{S}$, and von Kossa techniques. A negative reaction was obtained with Perl's Prussian blue method. The application of Gram and ZN stains failed to reveal the presence of bacteria.

In many other areas, there was a somewhat granulomatous appearance imparted by von Hansemann cells containing MG bodies probably contained within a persisting tubular framework (Fig. 3).

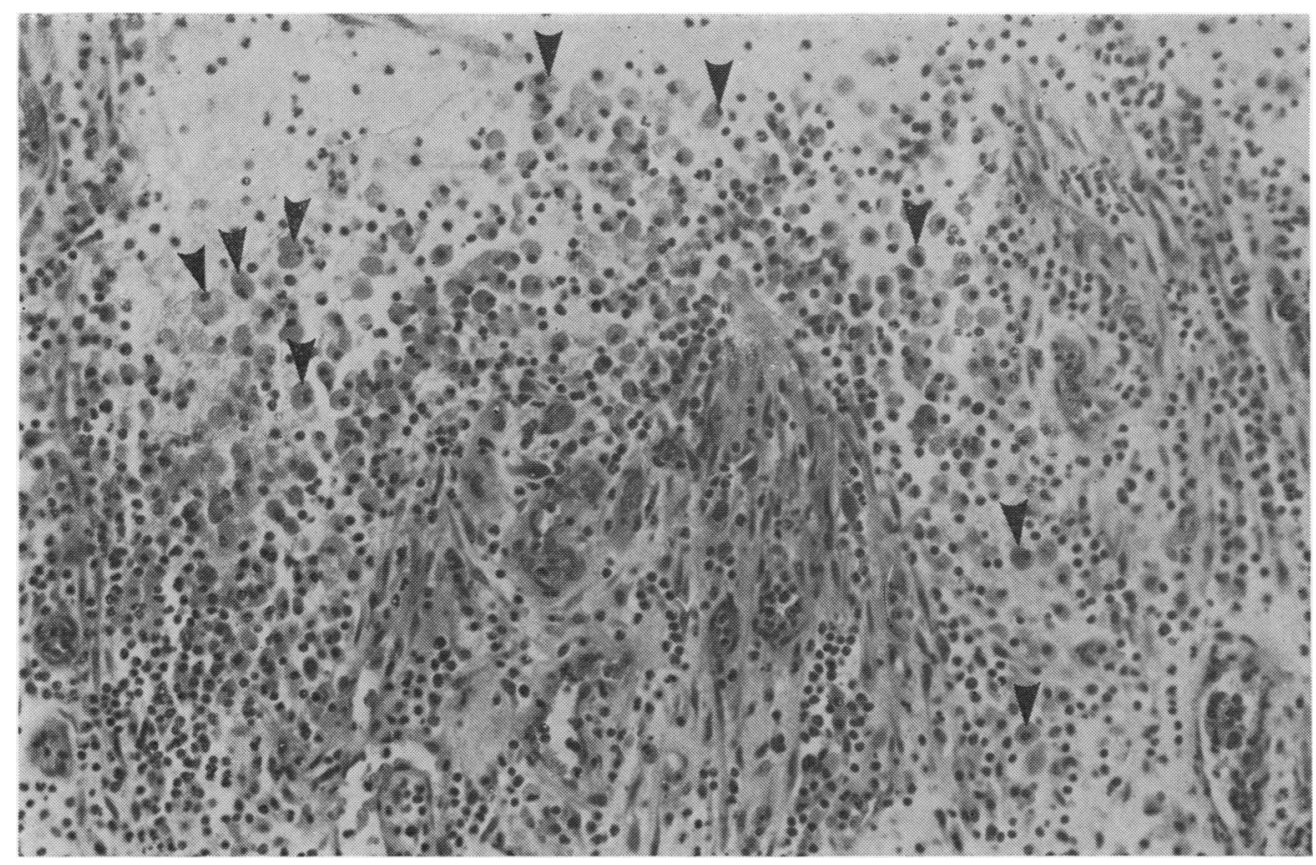

Fig. 1 Accumulation of numerous von Hansemann cells (arrowed) against a background of replacement of the tubular testicular architecture by granulation tissue. (Haematoxylin and eosin $\times 200)$. 


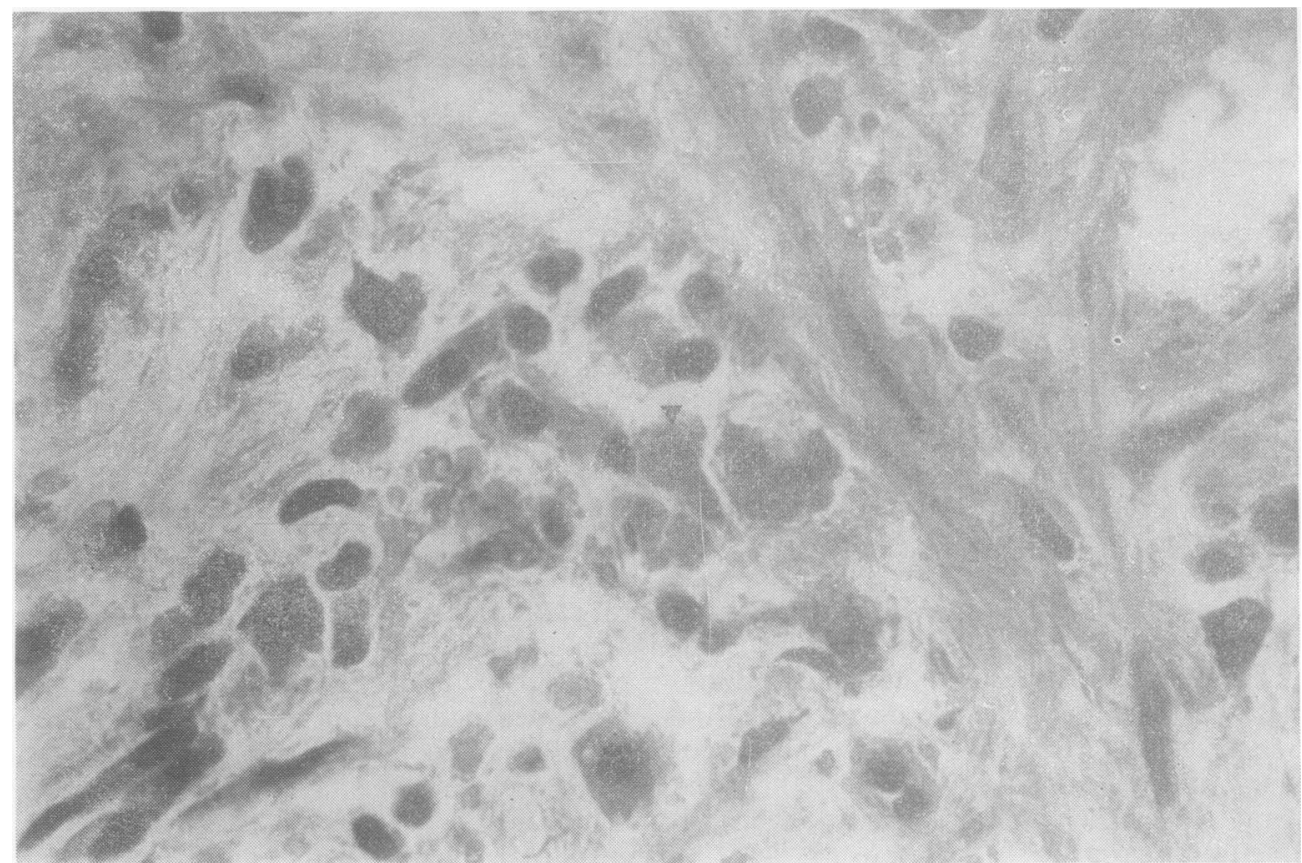

Fig. 2 A Michaelis-Gutmann $(M G)$ body is indicated in the cytoplasm of a von Hansemann cell. It shows a typical targetoid appearance. $(H$ and $E \times 1000)$.

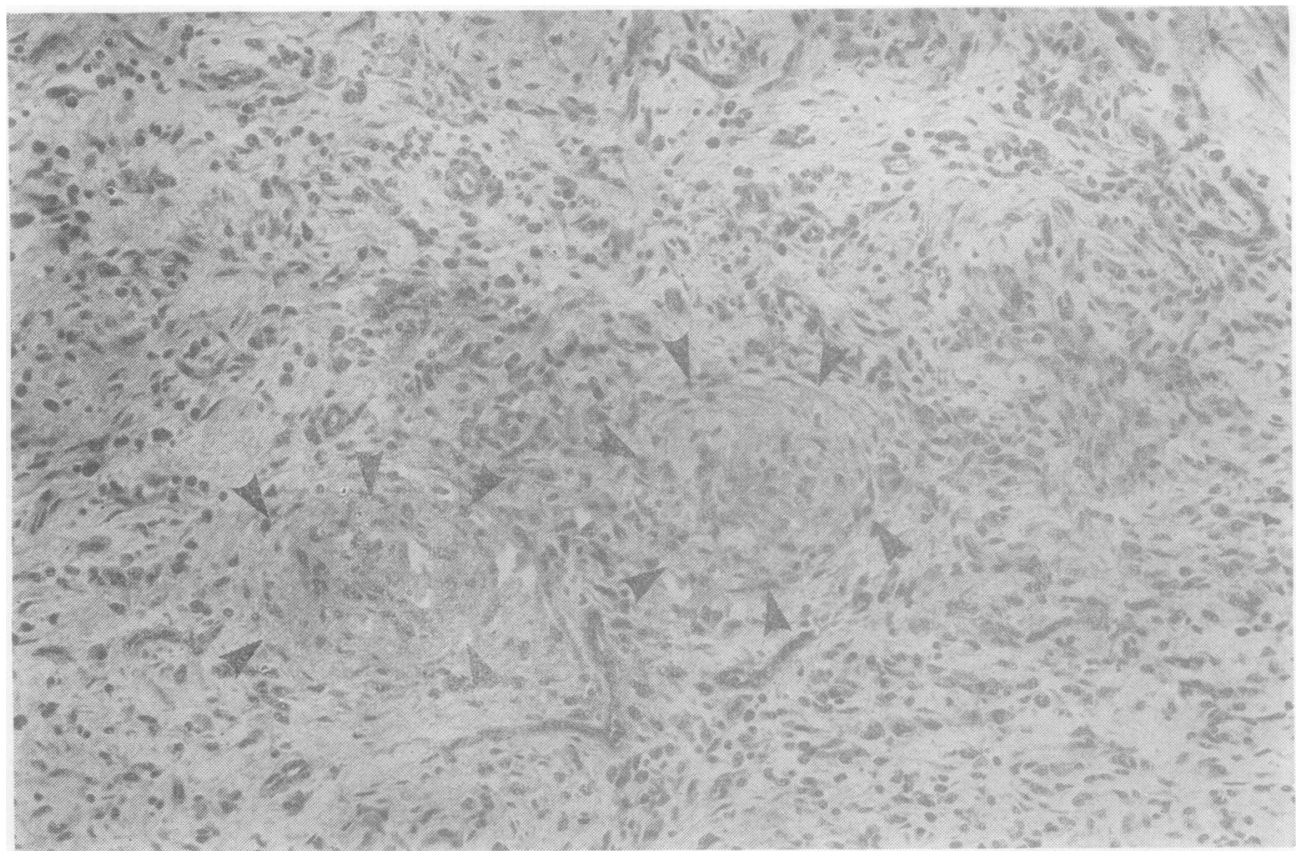

Fig. 3 Vague granulomatous appearance due to the presence of von Hansemann cells within a persisting tubular framework. The granulomatous structures are delineated by arrows. $(H$ and $E \times 400)$. 
CASE 2

A 39-year-old man developed a painful, swollen right testis one month after an episode of pain on micturition and haematuria (urine culture revealed a significant growth of Esch. coli). Haematological and biochemical indices were all normal, as was an intravenous pyelogram. There was nothing of significance in the past medical history. He was treated with antibiotics for the testicular swelling initially with good effect. The testicular swelling recurred after another month, and right orchidectomy was performed. The orchidectomy specimen weighed $111 \mathrm{~g}$, and the cut surface was pale and homogeneous. Histologically, there was a vaguely granulomatous appearance with poor delineation of groups of von Hansemann type cells containing Michaelis-Gutmann bodies and apparently based on tubular structures. Centrally, these structures contained acute inflammatory cells (Fig. 4). There was a fairly prominent lymphocyte infiltrate and some background fibrosis. The MG bodies reacted positively with the alizarin red S, von Kossa, and PAS methods (Fig. 5). The reaction with Perl's Prussian blue was negative, and bacteria were not visualised with the Gran or $\mathrm{ZN}$ methods.

\section{Results}

The survey of all cases of inflammatory testicular and epididymal disease revealed no additional cases of malakoplakia. There were 10 examples of granulomatous disease (Fig. 6). All these cases were ZN and Gram negative, and there were no foci of caseation. Round intracytoplasmic inclusion bodies were noted in seven cases (Fig. 7). These structures were PAS-positive and showed some variation in shape and size but they were generally of nuclear size. They reacted negatively with the von Kossa and alizarin red $\mathbf{S}$ techniques. These inclusions were plentiful in one case and only occasionally seen in the other six. In addition, many cells contained fine intracytoplasmic PAS-positive droplets. Structures with the morphological and histochemical characteristics of the Michaelis-Gutmann body were not identified in any of the cases. Multinucleated giant cells were noted in three cases. These exhibited both central and peripheral nuclear distribution, occupied central positions in the granulomata, and were not associated with caseation.

The remaining cases in the series exhibited either acute inflammatory changes $(18.9 \%)$, acute and

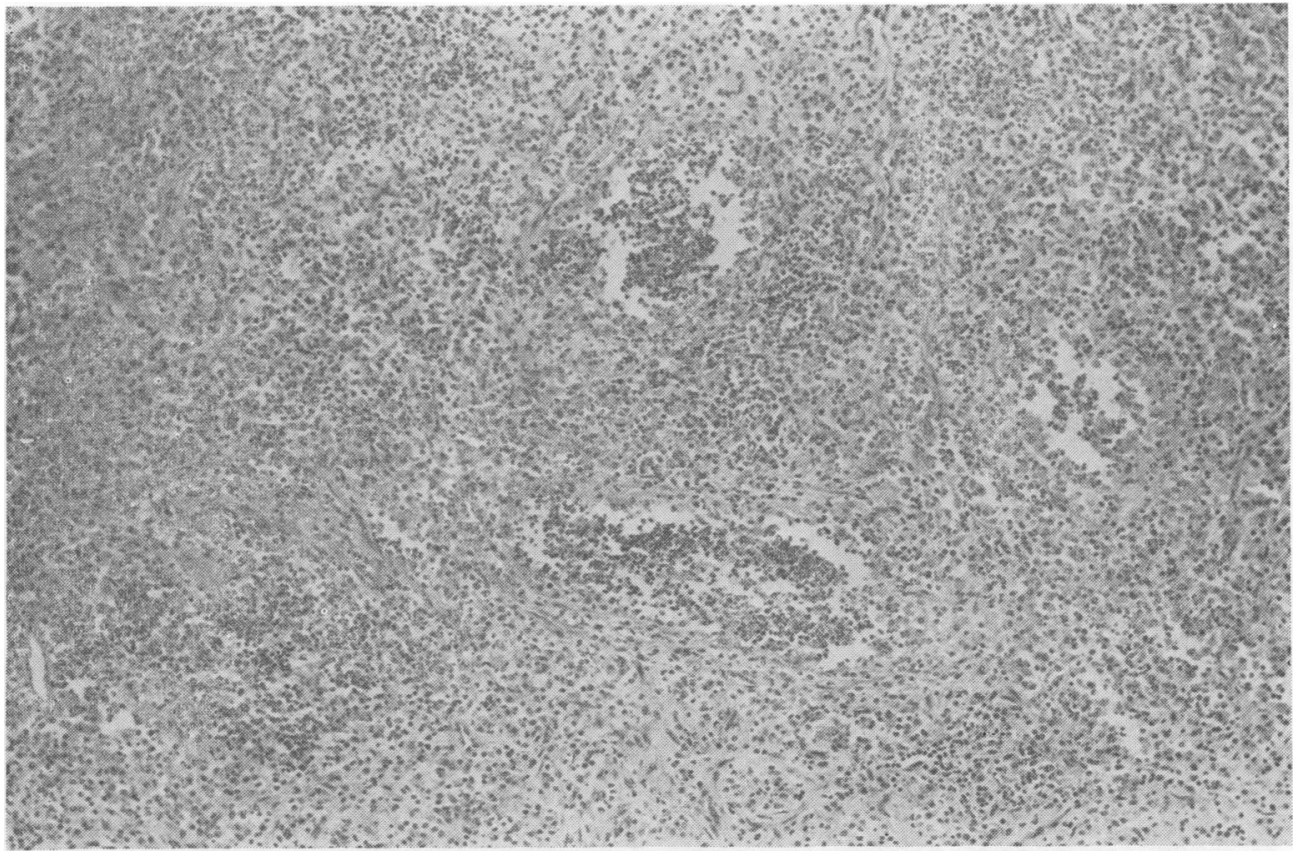

Fig. 4 Vaguely granulomatous structures probably based on the pre-existing tubular framework composed peripherally of von Hansemann cells and centrally of acute inflammatory cells. $(H$ and $E \times 200)$. 


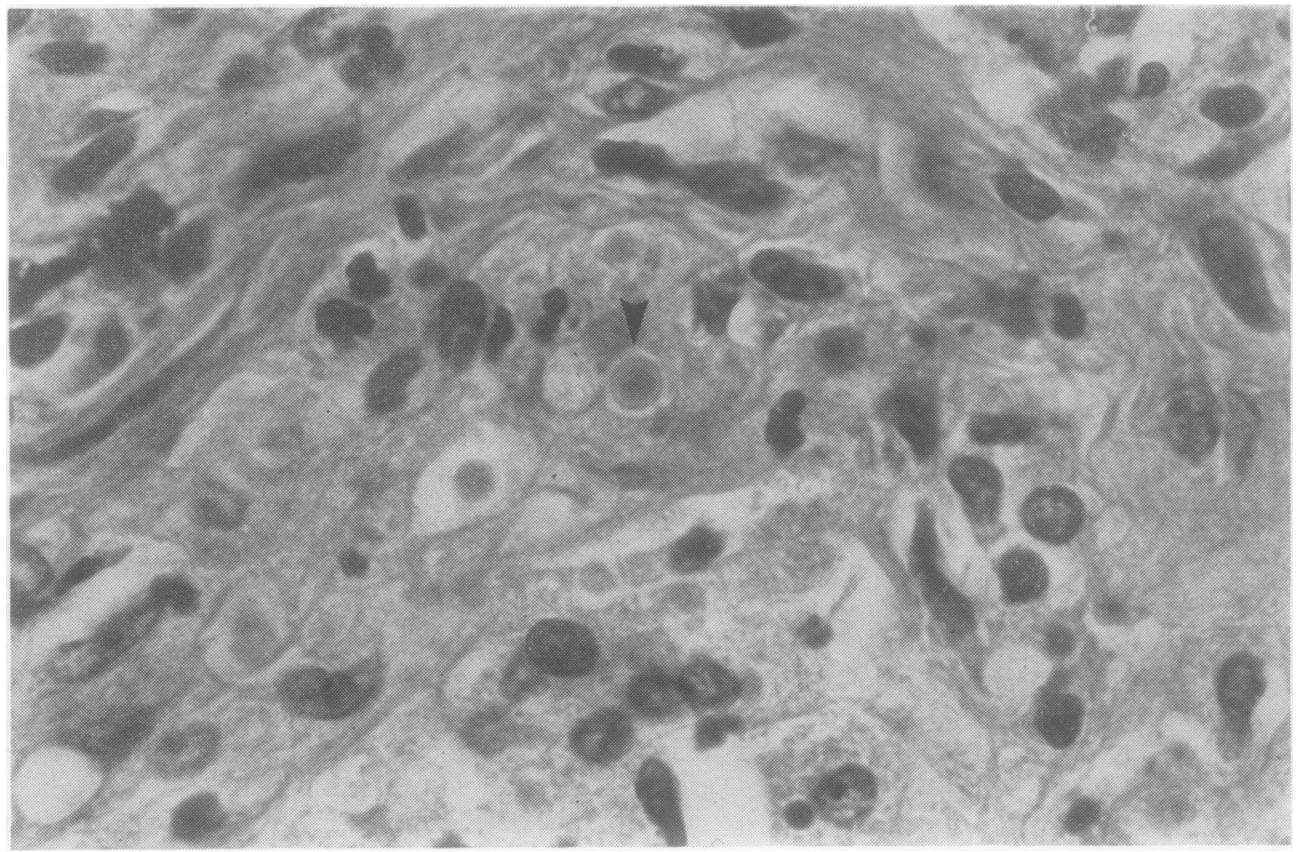

Fig. 5 An extracellular MG body is indicated by the arrow. $(H$ and $E \times 1000)$.

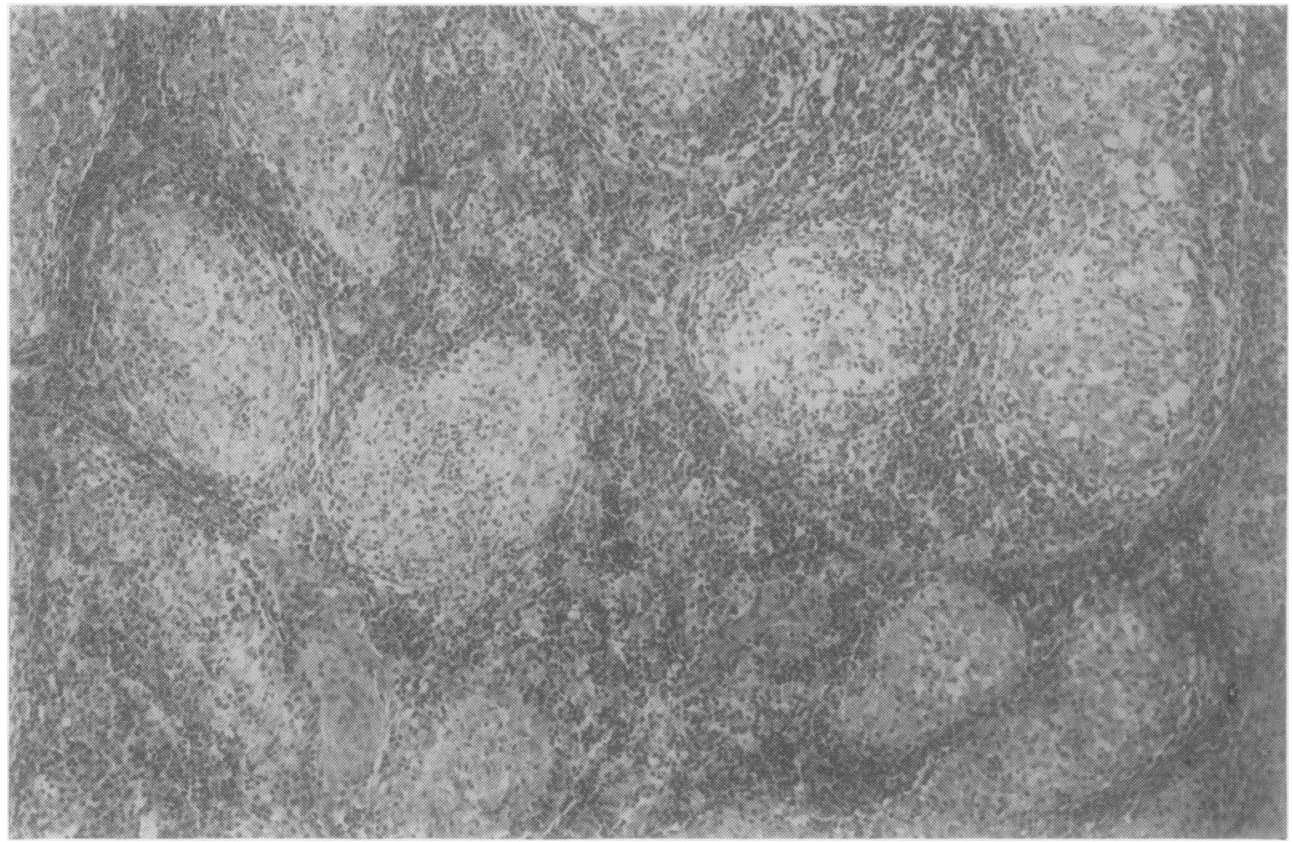

Fig. 6 This is the typical histological pattern of granulomatous orchitis. (H and $E \times 200$ ). 


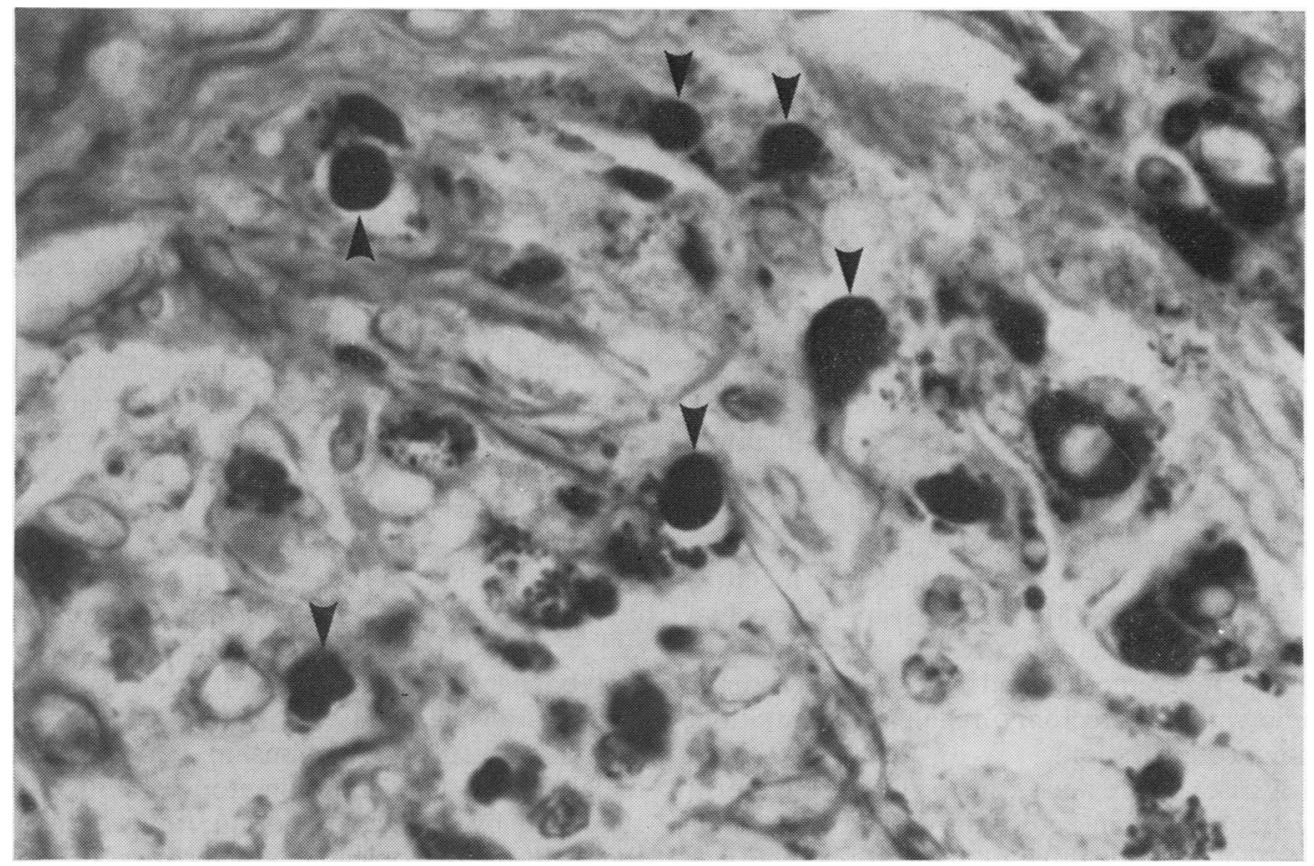

Fig. 7 The large PAS-positive inclusion bodies seen in some cases of granulomatous orchitis are arrowed. These are homogeneous and lack the targetoid appearance of MG bodies. $(P A S \times 1000)$.

chronic changes $(28 \cdot 3 \%)$, or chronic inflammatory changes $(35.0 \%)$ with no specific or characteristic features.

\section{Discussion}

Malakoplakia of the testis was first described by Haukohl and Chinchinian in $1958 .^{4}$ Most of the reports since then have described involvement of both testis and epididymis. Green ${ }^{10}$ described the first example of malakoplakia restricted to the epididymis, and two other cases of epididymal disease have been described by Clay et al. ${ }^{11}$ and Schornagel et al..$^{12}$ Nistal et al..$^{13}$ stated that they had studied three cases of epididymal malakoplakia, but their paper is devoid of clinical and histopathological detail.

Papers which describe malakoplakic disease of the epididymotesticular apparatus include those by Blackwell and Finlay-Jones, ${ }^{13 \mathrm{a}}$ Beskid and Gawlik, ${ }^{14}$ Brown and Smith, ${ }^{14 a}$ Waisman and Rampton, ${ }^{15}$ Lagacé, ${ }^{16}$ Yang and Marathe, ${ }^{17}$ Shaba and Black, ${ }^{18}$ Mikuz, ${ }^{19}$ Csapó and Gervain, ${ }^{20}$ Tamura and Iannotti, ${ }^{21}$ Dionne et al. ${ }^{22}$ Sterling et al., ${ }^{23}$ Bradley, ${ }^{24}$ McClure et al., ${ }^{25}$ and Rinaudo et al. ${ }^{26}$

A survey of the available literature on malakoplakic disease of the testis and paratesticular apparatus indicates a total of 36 cases (including the two reported herein). Adequate information is given on 29 of these cases. Of the remaining seven cases, three are said to be epididymal lesions ${ }^{13}$ and two are testicular. ${ }^{19}$ No clinical details are given of the latter cases, and histologically both would seem to be examples of granulomatous orchitis and only one case appears to exhibit typical Michaelis-Gutmann bodies. Schneider et al. ${ }^{27}$ refer to two cases, one of involvement of both testis and epididymis with microabscess formation in a 24-year-old, and the other of testicular disease in a 60 -year-old. No further information is given in either case.

Of the 36 reported cases, 23 have been involvement of the testis only, seven of testis and epididymis, and six of epididymis only.

For the purposes of this discussion, disease of the testis and testis plus epididymis are considered together.

As indicated above, four cases have inadequate information, and one of these is a doubtful diagnosis. ${ }^{19}$ In addition, the case reported by Shaba and Black, ${ }^{18}$ although accepted for publication as a case of malakoplakia, does not exhibit typical MichaelisGutmann bodies, and this was attributed to a decalcification occurring during fixation. This case has been excluded from consideration. Therefore, of the 28 reported cases of malakoplakia of the testis and testis plus epididymis, 25 are available for 
analysis. The cases of epididymal disease have been excluded from the present consideration.

The age of reported cases ranged from 23 to 70 years with a mean of 49.04 years. In $75 \% 18$ of cases, the lesion involved the right testis. Swelling and pain were the most common sign and symptom, occurring in 23 cases. The duration of these ranged from one to 12 weeks with a mean of 5.68 weeks. Swelling only occurred in two cases with a duration of eight weeks in one and three years in the other. In 15 of the cases there was no other illness, and in the remaining 10, the following conditions were present: (1) hepatic cirrhosis, (2) diabetes mellitus, (3) chronic renal failure, hypertension, and haemorrhagic pneumonitis, (4) gonorrhoea and renal calcification, (5) gonorrhoea and peptic ulcer, (6) coronary artery disease and diabetes mellitus, (7) chest infection, (8) metastasising bronchial carcinoid with an ectopic ACTH syndrome, (9) pulmonary tuberculosis, and (10) Goodpasture's syndrome with nephrectomy, renal transplantation, and immunosuppression.

In five cases, there was a history suggestive of a urinary tract infection before the onset of testicular swelling and pain. In three of these, Esch. coli was cultured from the urine at the time of the initial attack of urinary tract symptoms. Between the onset of testicular swelling and pain, 15 cases were treated with antibiotics. In 12 cases, urine culture was performed at the time of initial presentation of testicular swelling and pain. In six, there was a significant growth of Esch. coli and, in one, Klebsiella pneumoniae. In five cases the urine was sterile.

In eight cases the weight of the orchidectomy specimen was given, and this ranged from 45 to 111 with a mean of $72 \cdot 13 \mathrm{~g}$. Material was taken from the testicular tissue at the time of orchidectomy in six cases and cultured for microorganisms. Esch. coli was cultured in four cases, $\mathrm{Kl}$. pneumoniae being also found in one case. Aerobacter aerogenes was found in one case and Proteus species in another.

Microscopically, Gram-negative bacilli were found in six cases. Electron microscopy revealed organisms in one case. Organisms were not found in nine cases, and in one of these plus two other cases, bacteria were not seen by electron microscopy. In the remaining cases, no reference was made to organisms or to any attempt to identify them.

In six cases, there was involvement of the scrotal skin with sinus formation. In three cases, there had been previous ligation of the vas deferens, and in five, there was a prostatomegaly. Early papers on testicular malakoplakia had suggested an association with ligation of the vas deferens and prostatomegaly, but this now appears to be an infrequent association.

The staining reactions of the Michaelis-Gutmann bodies were such that the von Kossa reaction was positive in 25 cases, as was the PAS stain. Positive iron staining was obtained in 20 of the 25 cases. Alizarin red $\mathbf{S}$ was performed in two and was positive in both. Sudan black was applied to two with one positive and one negative. The Feulgen stain was done in one case and it was positive. Acid phosphatase staining was performed in one case and found to be positive.

That there is an association with urinary tract infection seems to be quite strongly supported in that significant microorganismal culture growth was obtained in six of the 12 cases in which it was sought. Organisms were also demonstrated in the malakoplakic tissue although this was by no means invariable.

Malakoplakia appears to represent an altered interaction between host macrophages and bacterial cell products, ${ }^{28}$ and therefore viable intact organisms will be demonstrated only relatively early in the evolution of the disease.

That there is a relationship between testicular malakoplakia and granulomatous orchitis was first suggested by Mikuz, ${ }^{19}$ who studied two cases with the light-microscopical characteristics of granulomatous orchitis. The particular histological characteristics of this lesion are large, round to polygonal cells with eosinophil cytoplasm which occupy the tubular spaces and thereby adopt a granulomatous pattern. The histogenesis of these cells is controversial. Gruenberg ${ }^{29}$ and, later, a number of other authors ${ }^{30-37}$ interpreted them as derivatives of Sertoli cells. However, others ${ }^{38-40}$ were of the opinion that they originated from the macrophage mononuclear system. Originally, sperm extravasates were considered responsible for granulomatous orchitis but, in spite of extensive search, sperms or sperm residue could not be demonstrated in typical lesions. ${ }^{38}$ Hubsmith et al. ${ }^{41}$ and Phillips ${ }^{42}$ thought that the cause of granulomatous orchitis was the acid fast lipids which Berg ${ }^{43}$ had isolated from sperm heads. Bünzli, ${ }^{44}$ however, could find this lipid in very few cases and then in small amounts.

The frequent clinical association between granulomatous orchitis and urinary tract infection was noted by Morgan ${ }^{45}$ and Lynch et al. ${ }^{\mathbf{4 6}}$ The latter reported culture of coliforms from the urine of $50 \%$ of their cases and suggested that the lesion could represent incomplete resolution of an inflammatory process.

Mikuz, ${ }^{19}$ as a result of electron microscopic studies, concluded that the controversial cell in granulomatous orchitis was a macrophage and that the PAS-positive granules were phagosomes. In one case, structures with the histochemical and ultrastructural characteristics of Michaelis-Gutmann 
bodies were present. Michaelis-Gutmann bodies are characteristic of malakoplakia and are giant phagosomes exhibiting an intraphagosomal calcification. Therefore, one of Mikuz's cases was also an example of malakoplakia. In both cases, intracellular bacilli were convincingly demonstrated in phagocytic vacuoles.

Dionne et al..$^{22}$ also described a case with the light microscopical features of granulomatous orchitis in which occasional Michaelis-Gutmann bodies were demonstrated. PAS-positive diastase-resistant cytoplasmic granules were also present and these were more abundant. Ultrastructurally, Dionne et al. claimed that, in addition to macrophages, there were cells with abundant cell junctions containing phagosomes and Michaelis-Gutmann bodies. These were considered to be Sertoli cells acting as facultative macrophages. Dionne et al. did not demonstrate intracellular bacteria in their case.

Features of the two cases which are the subject of the present report provide further evidence of a link between granulomatous orchitis and malakoplakia. The second case had originally been reported as granulomatous orchitis, and the light microscopical appearances justify this diagnosis. Special stains demonstrate the presence of MG bodies in constituent cells of these granulomatous areas, indicating that the lesion is also malakoplakic. The MG bodies are here less numerous in the second than in the first case, in which there were mainly areas of diffuse infiltration of von Hansemann cells and which was originally interpreted as an interstitial cell tumour. Areas of the first case also showed a vaguely granulomatous appearence. Acute inflammation was seen in both cases and was more severe in the first. In neither case were bacteria demonstrated at the light microscopic level. However, significant growths of Esch. coli had been obtained by culture from the urine of both cases.

This is in keeping with the finding that there is a substantial association of coliform urinary infection with testicular malakoplakia and also apparently with granulomatous orchitis. Assuming that testicular infection may be acquired by retrograde spread from the urinary tract and is therefore initially intratubular, the Sertoli cells and perhaps recruited macrophages may interact with bacteria and bacterial products with the formation of intracellular phagosomes. These would appear as PAS-positive granules of varying size, and if the host/organism interaction persisted at this level, then the result could be a granulomatous lesion with prominent PAS-positive inclusions and a pattern that would be determined by the tubular framework. This would be a granulomatous orchitis. In the present series, seven of 10 cases of granulomatous orchitis contained PAS-positive inclusions which were of variable size but particularly large and prominent in one case. If there was continuing or recurrent bacterial infection or if infection was by a large number of organisms, then the phagosomes might fuse to form giant cytosegrosomes which undergo calcification resulting in $\mathrm{MG}$ bodies. The more classical pattern of malakoplakia would then occur if the ongoing inflammatory reaction extended beyond the tubular confines, becoming diffuse. Therefore granulomatous orchitis and malakoplakia are seen as different stages in the progression of a similar pathological process.

The importance of recognising malakoplakia of the testis lies in not confusing it with other diseases such as interstitial cell tumour, histoplasmosis, and cryptococcus, as has occurred in the past. Accurate diagnosis involves an awareness of the condition and the use of special stains to demonstrate the presence of MG bodies. Cases of granulomatous orchitis should also be subjected to the von Kossa, PAS, and Perl's staining reaction to determine the incidence of MG bodies and to help either substantiate or refute the postulated relationship between these two conditions.

\section{References}

${ }^{1}$ Michaelis L, Gutmann C. Ueber Einschlüsse in Blasentumoren. Z Klin Med 1902;47:208-15.

2 von Hansemann D. Über Malakoplakie der Harnblase. Virchows Archiv Pathol Anat 1903;173:302-8.

${ }^{3}$ McDonald S, Sewell WT. Case of uncommon granuloma of kidneys and bladder. J Pathol Bacteriol 1912;17:115-6. (Abstract)

${ }^{4}$ Haukohl RS, Chinchinian H. Malakoplakia of the testicle. Am J Clin Pathol 1958;29:473-8.

${ }^{5}$ Reference deleted.

${ }^{6}$ Reference deleted.

${ }^{7}$ Hoffmann E, Garrido M. Malacoplakia of the prostate: report of a case. J Urol 1964;92:311-3.

${ }^{8}$ Coup AJ. Malakoplakia of the prostate. J Pathol 1976;119:119-21.

${ }^{9}$ Finlay-Jones LR, Blackwell JB, Papadimitriou JM. Malakoplakia of the colon. Am J Clin Pathol 1968; 50:320-9.

10 Green WO, Jr. Malacoplakia of the epididymis (without testicular involvement): the first reported case. Arch Pathol Lab Med 1968;86:438-41.

11 Clay A, Buffin RP, Dupont A, Houcke M, Lufiacre M. Étude anatomo-clinique d'une observation de malacoplasie à localisation épididymaire. Lille Méd $1971 ; 16: 1089-92$.

${ }^{12}$ Schornagel JH, Wagenaar SS, de Maat CEM. Malakoplakie: ein zeldzame solitaire localisatie in de epididymis. Ned Tijdschr Geneeskd 1976;120:1937-41.

${ }^{13}$ Nistal M, Rodriguez Echandia EL, Paniagua R. Septate junctions between digestive vacuoles in human malakoplakia. Tissue Cell 1978;10:137-42. 
${ }^{13 a}$ Blackwell JB, Finlay-Jones LR. Malakoplakia of the testis. J Pathol Bacteriol 1959;78:571-4.

14 Beskid M, Gawlik Z. Granuloma histiocyticum prostatae et testis. Extravesikale Lokalisation der Malakoplakie. Virchows Arch (Pathol Anat) 1965; 339:304-7.

${ }^{14 a}$ Brown RC, Smith BH. Malakoplakia of the testis. Am $J$ Clin Pathol 1967;47:135-47.

15 Waisman J, Rampton JB. Malacoplakia of the testis and epididymis. Arch Pathol Lab Med 1968;86: 431-7.

16 Lagacé R. Malakoplakia du testicule. Laval Méd 1969;40:276. (Abstract)

17 Yang YH, Marathe RL. Malacoplakia of the testis and epididymis (macrophagic-inclusion epididymoorchitis). Urol Int 1969;24:364-71.

${ }^{18}$ Shaba JK, Black WA. Malacoplakic granuloma of the testis. J Urol 1971;105:687-91.

19 Mikuz G. Elektronenmikroskopische Untersuchung an zwei Fällen granulomatöser Orchitis. Virchows Arch (Pathol Anat) 1973;360:223-34.

${ }^{20}$ Csapó Z, Gervain M. Testicular malacoplakia. (Hungarian) Orv Hetil 1974;115:87-9.

21 Tamura H, Iannotti HM. Ultrastructure of the Michaelis-Gutmann body. A study of a case of testicular malacoplakia. Arch Pathol Lab Med 1974;98:409-13.

22 Dionne GP, Bovill EG, Seemayer TA. New fine structural observations in testicular malakoplakia: role of the Sertoli cell. Urology 1975;5:828-34.

${ }^{23}$ Sterling WA, Hathaway BM, Courington DP, Diethelm AG. Malakoplakia in a renal transplant recipient. Transplantation 1975;20:420-4.

24 Bradley GE. Malakoplakia of the testis. NZ Med J 1976;83:77-9.

${ }^{25}$ McClure J, Hadden DR, Mudd DG, Parks TG. Adreno-cortical hyperactivity with disseminated malacoplakia. J Clin Pathol 1977;30:206-11.

${ }^{26}$ Rinaudo P, Damjanov I, Stoesser B. Malacoplakia of testis. Int Urol Nephrol 1977;9:249-54.

${ }^{27}$ Schneider C, Dor AM, Basbous D, Lebreuil G. La malacoplasia: formes anatomo-cliniques. Revue de la littérature, à propos de 15 observations personnelles. Arch Anat Pathol 1975;23:199-208.

${ }^{28}$ Csapó Z, Kuthy E, Lantos J, Ormos J. Experimentally induced malakoplakia. Am J Pathol 1975;79:453-62.

29 Gruenberg H. Ueber drei ungewöhnliche Fälle von chronischer Orchitis unter dem klinischen Bilde eines
Hodentumors. Frankfurter $Z$ Pathol 1925;33:217-2.

${ }^{30}$ Dieterle $R$. Über eigenartige geschwulstähnliche Epithelwuncherung bei chronischer orchitis. Schweiz Z Allg Pathol 1950;13:265-78.

${ }^{31}$ Dreyfuss W. Acute granulomatous orchitis. J Urol 1954;71:483-7.

${ }^{32}$ Spjut H J, Thorpe JD. 'Granulomatousorchitis.' $A m$ J Clin Pathol 1956;26:136-45.

${ }^{33}$ Capers TH. Granulomatous orchitis. Am J Clin Pathol 1960;34:139-45.

${ }^{34}$ Aboulker P, Roujeau J, Chomé J. Étude anatomique de sept cas d'orchite granulomateuse. Presse Méd 1964:72:1855-8.

${ }^{35}$ Cullen TH, Voss HJ. Sperm granulomata of the testis and epididymis. Br J Urol 1966;38:202-7.

${ }^{36}$ Balouet G, Daoulas R, Campenon F, Ollier L. Deux cas d'orchite granulomateuse et giganto-cellulaire pseudotumorale. Arch Anat Pathol 1967;15:30-3.

37 Nichelatti T, Milani C. Orchite cronica granulomatosa. Arch De Vecchi Anat Patol 1967;49:445-58.

${ }^{38}$ Friedman NB, Garske GL. Inflammatory reactions involving sperm and the seminiferous tubules: extravasation, spermatic granulomas and granulomatous orchitis. J Urol 1949;62:363-74.

${ }^{39}$ Batzenschlager A, Prévot R. L'orchi-épididymite chronique histiocytaire et gigantocellulaire résorptive. J Urol Med Chir 1959;65:566-77.

40 Alberto P. L'orchite histiocytaire. J Urol Nephrol (Paris) $1963 ; 69: 357-72$.

41 Hubsmith RJ, Garret R, Photos C. Granulomatous orchitis and epididymitis. J Urol 1959;81:301-4.

42 Phillips DEH. Lipid granulomata of the testis and epididymis. Br J Urol 1961 ;33:448-52.

${ }^{43}$ Berg JW. Differential staining of spermatozoa in sections of testis. Am J Clin Pathol 1953;23:513-5.

44 Bünzli HF. Formen granulomatöser Orchitis. Virchows Arch (Pathol Anat) 1968;345:33-44.

${ }^{45}$ Morgan AD. Inflammatory lesions simulating malignancy. Br J Urol 1964;36:Suppl 95-102.

${ }^{46}$ Lynch VP, Eakins D, Morrison E. Granulomatous orchitis. Br J Urol 1968;40:451-8.

Requests for reprints to: $\mathbf{J}$ McClure, Division of Tissue Pathology, Institute of Medical and Veterinary Science, Box 14 Rundle Street Post Office, Adelaide, South Australia 5000. 